\title{
A multi-criteria evaluation of the European cities' smart performance: Economic, social and environmental aspects*
}

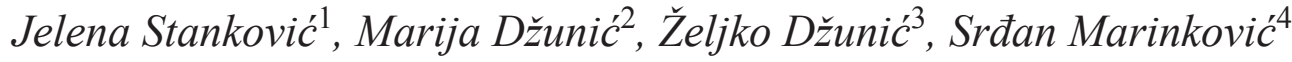

\begin{abstract}
The purpose of the paper is to provide the ranking of Central and Eastern European cities, based on various elements of cities' smart performance. Our analysis enables the evaluation of social, economic and environmental aspects of urban life that represent the determinants of cities' competitive profiles and consequently, the positions on the ranking lists. The research is based on the data on perceptions of citizens on different aspects of urban quality, provided by the Eurostat's Urban Audit Perception Survey. For the assessment of various hierarchically structured indicators of cities' smart performance, a multi-criteria analysis model is developed, combining the AHP (Analytic Hierarchy Process) for determining the relative importance of criteria and TOPSIS (Technique for Order Preference by Similarity to Ideal Solution) method of ranking. The main finding of the paper implies that direct perceptions of citizens on the overall life satisfaction in the analyzed European cities are not influenced by their smart performance. The comparison of ranks obtained by the constructed multi-criteria model and perceived satisfaction of life indicates a rather weak relation.
\end{abstract}

Key words: smart cities, urban development, multi-criteria analysis, sustainability, infrastructure

JEL classification: $C 44,018$

\footnotetext{
Received: 7-03-2017; accepted: 21-12-2017

1 Associate professor, University of Niš, Faculty of Economics, Trg Kralja Aleksandra 11, 18000 Niš, Serbia. Scientific affiliation: quantitative economics. Phone: +381 18528 655. E-mail: jelena.stankovic@eknfak.ni.ac.rs (correspondingauthor).

2 Associate professor, University of Niš, Faculty of Economics, Trg Kralja Aleksandra 11, 18000 Niš, Serbia. Scientific affiliation: political economy. Phone: +381 18528 683. E-mail: marija dzunic@ni.ac.rs.

${ }^{3}$ IT consultant, University of Niš, JUNIS, Univerzitetski trg 2, 18000 Niš, Serbia. Scientific affiliation: information systems.Phone: +38162445 307.E-mail: z.dzunic@ni.ac.rs.

${ }^{4}$ Full professor, University of Niš, Faculty of Economics, Trg Kralja Aleksandra 11, 18000 Niš, Serbia. Scientific affiliation: finance and banking. Phone: +381 18528 604. E-mail: srdjan. marinkovic@eknfak.ni.ac.rs.
} 


\section{Introduction}

In the last decades, the smart city concept has been drawing increased attention among academic researchers and policymakers. It has become a popular catchphrase that captures a variety of aspects, approaches and notions, therefore being difficult to strictly delineate. As such, smart city turns to be a profoundly interdisciplinary subject with a proliferating use in many different fields.

Substantial challenges arising from rapid urbanization and unsustainable forms of existing urban areas have brought the smart city concept to the fore of contemporary urban policy debates, as a promising framework for sustainable urban development. The concept comprises creative and innovative solutions based on harnessing technologies in various aspects of urban living, integrating its economic, social, environmental and governmental dimensions. It is seen as a holistic process of redesigning urban areas, aimed at achieving sustainable urban growth, efficient service systems and increasing the citizens' quality of life.

The development of the concept included various aspects of urban development - economy, society, governance, environmental conditions. The performance of a city in each of these areas can be assessed as a strength or weakness in the competitive game between urban regions in their attempt to attract business, educated workforce, or to improve the city image. City rankings have appeared as useful tools for comparing cities regarding their state of smart development and identifying areas that need further improvements, providing significant inputs for urban policy creation. The most influential rankings are Cities of Opportunity (PricewaterhouseCoopers, 2014), Hot Spots 2025 (Economist Intelligence Unit, 2013), Global Power City Index (Mori Memorial Foundation, 2015), Global Cities Index and Emerging Cities Outlook (A.T. Kearney, 2015), europeansmartcities (Vienna University of Technology, 2015). Most of the rankings are performed by assessing citizens' perceptions on various aspects of urban living, including quality of services provided in the cities, employment prospects, housing conditions, the level of social integration and safety and the effectiveness of local government administration.

The aim of this paper is to evaluate different aspects of smart performance of Central and Eastern European cities, compared to citizens' subjective perceptions on the overall quality of life in their cities. The cities will be ranked according to several groups of criteria, representing different aspects of urban living, as perceived by the citizens. As a result, a city ranking list will be created, pointing to main strengths and difficulties of living in analysed cities.

The main hypothesis of the paper is that there is a strong coherence between composite measure of city's smart performance and the citizens' direct perceptions on the quality of life. 
The scientific contribution of the paper is twofold. Contributions to theory are reflected in developing a novel approach for measuring smart performance of the city. Empirically, the paper contributes to the existing literature on city rankings and evaluation of quality of life, by testing the model with empirical data on Central and Eastern European cities. The results provide an insight on the relations between the level of city's smart performance and the perceived quality of life in the observed city.

The paper will be structured as follows: after introductory notes, a brief literature review on the development of the smart city concept and its multidimensional nature will be presented. In the next chapter, model development and methodology will be described, followed by data sources used in the paper and presentation and discussion of main results derived by the multi-criteria analysis. Finally, concluding remarks will be offered.

\section{Literature review}

Despite the growing academic attention, there is still unclear and inconsistent understanding of the smart city concept, owing to a visible fragmentation in the defining approaches. Instead of a universally agreed upon definition, there is a variety of definitions available, leading to a confusion among urban policy makers aimed at defining proper policies for urban development. One common aspect of the majority of different defining approaches is the notion of information and communication technologies (hereinafter ICT) being central to the functions, services and designs of urban areas (Bibri and Krogstie, 2017). However, the smart city concept is far from being limited to the use of technologies in the cities (Albino et al., 2015). It is aimed at creating policies that target sustainable development, economic growth and quality of life of its citizens (Ballas, 2013). In other words, the main purpose of ICT diffusion is to enhance the quality of life (Batty et al., 2012).

It is mostly agreed that the smart city concept originates back from late 1990s, related to the smart growth movement (Dameri and Cocchia, 2013; Neirotti et al., 2014; Batty et al., 2012). At the time, the concept was mostly used in the context of implementing ICT in designing modern city infrastructures that would enable efficient use of energy, land, transportation (Alawadhi et al., 2012). However, this approach has later been criticized by authors accentuating the need to account for social relations as an important urban development resource. Consequently, there are two main approaches in defining the smart city, reflecting the distinction between hard infrastructure, encompassing physical infrastructure and ICTs and soft infrastructure that relates to social and human capital, knowledge, policy innovations, cultural heritage and citizens' participation (Del Bo and Florio, 2008; Angelidou, 2014). 
The first, technology oriented approach, defines the concept of smart city as the use of a wide range of sophisticated ICTs (smart grid, transportation systems, traffic regulation) in strengthening the efficiency of urban systems (Lee et al., 2013; Odendaal, 2003; Walravens, 2012). Technological factors are considered key stones of smart cities' future operation (Aurigi, 2005), with majority of definitions stressing the role of ICT in various areas - economic, social, environmental and governmental (Hollands, 2008; Komninos, 2002). The central argument of this approach is that technology is the starting point for rethinking social issues - social inclusion, business-led growth, growth of creative industries, building social capital (Walravens, 2012). Smart city is defined as "the use of computing technologies in making the critical infrastructure components and services of a city, which include city administration, education, healthcare, public safety, real estate, transportation, and utilities - more intelligent, interconnected, and efficient (Washburn et al., 2010). The use of ICTs enable smart cities to optimize and integrate existing infrastructures and resources, and provide efficient services to citizens (Kitchin, 2013; Marsal-Llacuna et al., 2015). It is the cost reduction technologies - cheap mobile applications, free social media, cloud computing, big data handling that have enabled the development of urban functions in modern cities (Berst et al., 2013).

Another strand of literature insists on people-oriented approach. It focuses on human and social capital as distinctive resources of smart cities (Aguilera et al., 2013; Lombardi et al., 2011), as it allows connecting people and creating relationships (Alawadhi et al., 2012). According to Shapiro (2006), smart cities are areas with a large share of the adult population with a college degree. There is evidence that educated and skilled labour force has a decisive role in urban development (Glaeser and Berry, 2006). People employed in creative industries, such as science, engineering, education, computer programming and research contribute to urban performance (Florida, 2002). Therefore, education, learning, and knowledge are recognized as key drivers of a smart city (Thuzar, 2011). Establishing networks of productive interactions between urban actors and connecting knowledge centers enables the creation of innovation hubs (Kourtit et al., 2012). The means of social interactions between the citizens and city administrators, as well as the intensity of civic activism and social participation affect the development of social policies and practices (Mullen, 2014). Smart governance includes regulatory and compliance mechanisms, based on political participation, effective service provision and e-government. Achieving the right balance of state, market and civic society enables inclusive and democratic forms of development (Heller, 2013).

Integration of the above discussed approaches refers to the opinions that emphasize equal importance of technologies, people and governance (Hollands, 2008; Sauer, 2012). This is a holistic understanding of the intertwined processes of technological investments and environmental, social and economic developments (Batty et al., 
2012). Structuring the smart city categories into six broad characteristics (smart economy, smart people, smart governance, smart mobility, smart environment and smart living), a smart city is characterised as a "city well performing in a forward-looking way in these six characteristics, built on the smart combination of endowments and activities of self-decisive, independent and aware citizens." (Giffinger et al., 2007). A city is considered smart when "investments in human and social capital and traditional (transport) and modern (ICT) communication infrastructure fuel sustainable economic growth and a high quality of life, with a wise management of natural resources, through participatory governance" (Caragliu et al., 2011). An alternative term, smart sustainable city (SSC) is defined as "an innovative city that uses information and communication technologies (ICTs) and other means to improve quality of life, efficiency of urban operation and services, and competitiveness, while ensuring that it meets the needs of present and future generations with respect to economic, social and environmental aspects" (ITU, 2014).

This integrated view accentuates that technology is adapted in a way to empower citizens, rather than adapting citizens to the use of technologies (Vanolo, 2014). Smart city is regarded as a tool to achieve prosperity, effectiveness, and competitiveness (Angelidou, 2014) and to address social, economic and environmental problems (Townsend, 2013). However, vast amount of literature points out the role of smart cities in providing a better quality of life to its citizens (Neirotti et al., 2014, Khan et al., 2015). Chourabi et al. (2012) use the word smart in the sense of applying advanced ICT in order to improve efficiency, sustainability, equity and the quality of life. Smart cities offer advanced and innovative services to citizens in order to improve the overall quality of their life (Piro et al., 2014).

The identified aspects of smart cities have long been used as the grounds for performing city rankings. First attempts originate from the hedonic pricing literature (Nordhaus and Tobin, 1972; Roback, 1982). Various amenities of urban life, such as pollution, climate, population density, unemployment and crime have been used in the calculations of rent and land differentials across urban areas (Liu, 1977; Rosen, 1979; Berger et al. 2008). These calculations have served as the basis for constructing objective indices of the quality of life. A more recent line of research employs data on subjective perceptions of life satisfaction and quality, investigating the impact of various environment determinants (Frey and Stutzer, 2008; Welsch, 2006). In recent literature, the city rankings are considered an instrument for evaluating economic, social and environmental aspects of different cities that can be translated into applicable strategies and policies of urban development (Giffinger et al. 2007). 


\section{Model development and methodology}

As the aim of the paper is to establish a relation between smart performances of a city and the quality of life in that city and the data on citizens' perceptions of different categories of urban life are used for model development. We assessed 26 indicators that refer to smart performance of a city across five thematic categories: (1) infrastructure, (2) liveability and housing conditions, (3) environment, (4) employment and finance and (5) governance, urban safety, trust and social cohesion. In addition, we included two indicators that refer to citizens' perceptions on quality of life in the city, answering to the following questions: (1) Are you satisfied to live in this city and (2) Are you satisfied with the live you lead? Indicators represent the subjective perception of the inhabitants of the fulfilment of certain standards of urban life in their cities, while the authors' goal is to form groups of indicators that characterize certain thematic categories of smart city performance. Infrastructure, as the first category of smart performance include following indicators: public transport in the city, public spaces in this city such as markets, squares, pedestrian areas and availability of retail shops. Liveability and housing conditions include six different indicators such as health care services offered by doctors and hospitals in this city, schools in the city, sports facilities (e.g. sport fields and indoor sport halls), cultural facilities (e.g. concert halls, theatres, museums and libraries), easiness to find good housing at a reasonable price in the city and state of streets and buildings in neighbourhood. Environment is one of the typical parameter for assessment of smart performance of the city and for the purpose of model development, includes following indicators: green spaces such as public parks or gardens, degree of commitment in the city to the fight against climate change (e.g. reducing energy consumption in housing or promoting alternatives to transport by car), quality of the air in the city, noise level in the city and cleanliness in the city. Important economic issues are assessed trough criterion Employment and finance that includes four different indicators: easiness to find a good job in the city, having difficulty to pay bills at the end of the month, personal job situation and financial situation of household. Finally, large group of indicators is used to assess Governance, urban safety, trust and social cohesion. This thematic category includes indicators such as efficiency of administrative services of this city, trust in public administration of the city, level of integration of foreigners who live in this city, perception on presence of foreigners as good for this city, perception of whether the most people in this city can be trusted, perception on personal safety, perception on safety in the neighbourhood you live in and perception of whether the most people in my neighbourhood can be trusted.

Considering the indicators that determine the smart performance of cities have different relative importance for the quality of life in the city, the method of choice for solving the problem is multi-criteria analysis (MCA). The result of MCA application is creating a composite measure of fulfilment of all criteria related 
to aspects of smart performance in the observed city. Furthermore, it is possible to establish existence of coherency between composite measure of city's smart performance and the citizens' perceptions on quality of life given through answers whether they are satisfied to live in this city and with the live they lead.

In order to test the main hypothesis, multi-criteria model has been developed. For the purpose of the model development, thematic categories that include indicators of smart performance are marked as the criteria at the first level of hierarchy and labelled $C_{j}, j=\overline{1,5}$. The benchmark includes 26 qualitative indicators on citizens' perceived satisfaction with categories listed above. Those indicators are the subcriteria at the second level of hierarchy and the hierarchical structure of criteria is presented in the Figure 1.

Figure 1: Flowchart of Proposed Model

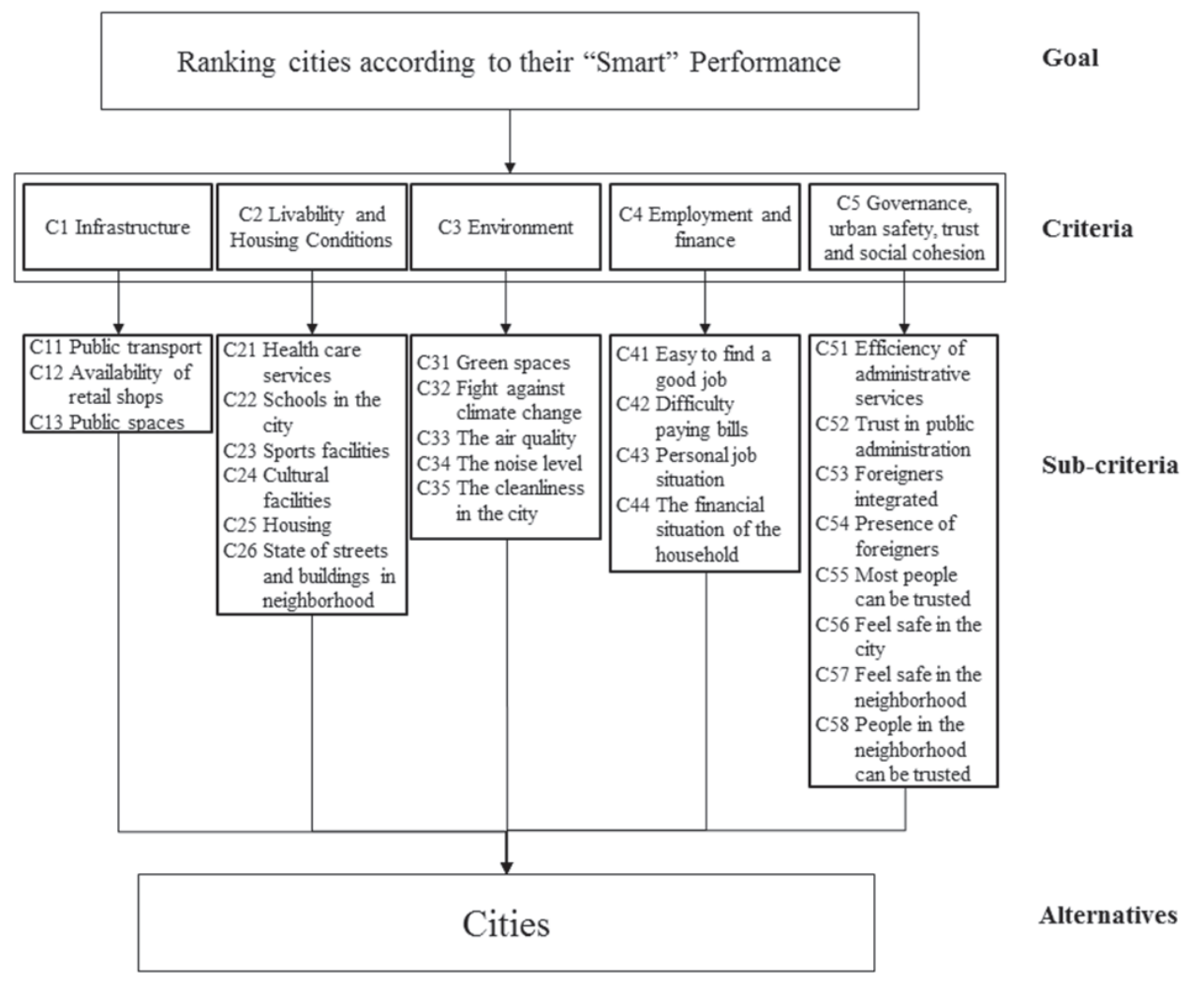

Source: Authors' preview of model development

At the lowest, third level of hierarchy are the alternatives, i.e. cities to be ranked. The form of the model corresponds to multi-criteria decision matrix. The method of 
choice for weights determination is Analytic Hierarchy Process, while TOPSIS is the ranking method to be used in this model.

\subsection{Weights determination using AHP}

Analytic Hierarchy Process (AHP) is one of the most commonly used methods of multi-criteria analysis developed by Thomas Saaty in 1977. The AHP algorithm is determined by set of principles and axioms that delimits the scope of the problem environment (Forman and Gass, 2001). Three basic principles of AHP are (1) decomposition, (2) comparative judgments and (3) hierarchic composition or synthesis of priorities (Saaty, 1994).

The purpose of decomposition is to structure a complex problem into clusters of different hierarchy: criteria, sub-criteria, sub-sub-criteria and so on. At the bottom level are alternatives that should be ranked according to higher levels of hierarchy. The principle of comparative judgments is applied to construct pairwise comparisons of all combinations of elements in a particular cluster with respect to the cluster of the higher level. First knowledge about pairwise comparison method was introduced by Fechner in 1860 and developed sixty years later by Thurstone in 1927. Based on this essential pairwise comparison method, Saaty developed the AHP as a method for multi-criteria decision-making (Saaty, 1980).

These pairwise comparisons are used to assess "local" priorities of the elements in a particular cluster with respect to their higher level cluster. The principle of hierarchical composition or synthesis is applied to the priorities of the elements in each cluster level and creates a kind of "general" priority vector for all elements and all hierarchy levels in the problem (pairwise comparison of criteria and alternatives at a given level of hierarchy, but also in relation to the criteria of the directly higher level). Pairwise comparison of alternatives carried out with reference to judgment on two observed attributes that characterize the pair of alternatives in respect to the given criteria, in terms of meeting the criteria and contribution to the proposed objective. Strength of preference is expressed by the ratio scale with increments of 1-9. The preferred level of 1 shows the equality of observed attributes, while the level of 9 indicates absolute, the strongest preference of one attribute over another (Ma and Zhang, 1991; Leskinen, 2000). Such a scale was formed by Saaty (Saaty, 1977) and it is used in essentially the AHP method and for its entire later advanced variant (revised AHP or Analytic Network Process).

The theory of AHP method is based on three axioms. The first axiom, the reciprocal axiom refers to forming decision matrix. Based on pairwise comparison reciprocal matrix $A_{n x n}$ has been formed, for each cluster respecting their parent in hierarchy above. The reciprocal matrix has elements $a_{i i}=1$, (the main diagonal elements are equal to one), while the elements below main diagonal are computed as the reciprocal of the elements above, i.e. $a_{j i}=1 / a_{i j}, \mathrm{i} \neq \mathrm{j}, i, j=1,2, \ldots, n(1)$ : 


$$
\left[\begin{array}{ccc}
1 & \cdots & a_{1 n} \\
\vdots & \ddots & \vdots \\
1 / a_{1 n} & \cdots & 1
\end{array}\right]
$$

The second is homogeneity axiom which suggests that the elements being compared through pairwise comparison should not be too different or there will tend to be larger errors in judgment. On the basis of this axiom it is implied that AHP method is not suitable for problems where there is a large number of criteria or alternatives.

The third axiom states that judgments about, or the priorities of, the elements in a hierarchy do not depend on lower level elements. This axiom is required for the principle of hierarchic composition to be applied. While the first two axioms are, in our experience, completely consonant with real world applications, the third axiom requires careful examination, as it is not uncommon for it to be violated (Forman and Gass, 2001).

The mathematical background of AHP algorithm for calculating the priorities is theory of consistent matrices as well as Perron-Frobenius theory on non-negative matrix (Perron, 1907; Frobenius 1912). Simply, whole algorithm is based on ability of eigenvector to generate true or approximate weights (Saaty, 1987). The AHP algorithm makes a comparison of criteria or alternatives with respect to an observed criterion, in pairwise mode. As a tool for pairwise comparison, AHP uses a fundamental scale of absolute numbers (from 1 to 9) that has been widely accepted in practice and validated by many different experiments in the field of decision theory (Saaty, 1977). This scale has to be a scale that quantifies individual preferences with respect to quantitative and qualitative attributes just as well or better than other scales.

According to the Perron-Frobenius Theorem, if $A$ is an $n \times n$, non-negative, primitive matrix, then one of its eigenvalues $\lambda_{\max }$ is positive and greater than or equal to (in absolute value) all other eigenvalues, and there is a positive eigenvector $W$ corresponding to that eigenvalue, and that eigenvalue is a simple root (matrix Frobenius root) of the characteristic equation. (Alonso and Lamata, 2006, p. 447):

$$
A W=\lambda_{\max } W \text { or }\left(A-\lambda_{\max } I\right) W=0
$$

If the pairwise comparison matrix is perfectly consistent, following statements are valid: (1) for arbitrary $i, j$ and $p, a_{i j} a_{j p}=a_{i p}(i, j, p=1, \ldots, n),(2)$ the comparison matrix determinant is equal to 0 and (3) the matrix Frobenius root i.e. eigenvalue $\lambda_{\max }$ is equal to $n$ and (4) the remaining eigenvalues are equal 0 for any $a_{i j}$. Thus, the eigenvector corresponding to the $\lambda_{\max }$ is always non-negative and each element of the eigenvector standardized by additive normalization can be interpreted as relative importance of corresponding criterion (Alonso and Lamata, 2006). 
In situation of perfect consistency, the comparison matrix satisfies the transitivity property for all pairwise comparisons. However, ideal judgments that decision matrix makes consistent are rare and it is necessary to determine the acceptable level of inconsistency. In this case, Saaty defined the consistency index $(C I)$ as follows:

$$
C I=\frac{\lambda_{\max }-n}{n-1}
$$

as well as consistency ratio:

$$
C R=\frac{C I}{R I}
$$

where $R I$ is the average value of $C I$ for random matrices using the Saaty scale. According to Saaty only acceptable inconsistency is if $C R<0.1$.

\subsection{Ranking algorithm of TOPSIS}

TOPSIS method represents a technique for ranking a number of alternatives, based on their distances to positive ideal and negative ideal solutions, as described in the following steps (Yoon and Hwang, 1995, pp. 39-41):

Step 1. Calculate the normalized decision matrix $R_{m \times n}=\left[r_{i j}\right]_{m \times n}$, where normalised values $r_{i j}$ are calculated as:

$$
r_{i n}=\frac{x_{i j}}{\sqrt{\sum_{i=1}^{m} x_{i j}^{2}}}, \quad i=1,2, \ldots, m, \quad j=1,2, \ldots, n
$$

Step 2. Calculate the weighted normalized decision matrix $V_{m \times n}=\left[v_{i j}\right]_{m \times n}$, where weighted normalised values $v_{i j}$ are determined as:

$$
v_{i j}=w_{j} r_{i j}, i=1,2, \ldots, m, j=1,2, \ldots, n .
$$

Step 3. Determining positive ideal $A^{*}$ and negative ideal $A^{-}$solutions based on given relations:

$$
\begin{aligned}
& A^{*}=\left\{v_{1}^{*}, v_{2}^{*}, \ldots, v_{j}^{*}, \ldots, v_{n}^{*}\right\}=\left\{\left(\max _{i} v_{i j} \mid j \in J_{1}\right),\left(\min _{i} v_{i j} \mid j \in J_{2}\right) \mid i=1,2, \ldots, m\right\} \\
& A^{-}=\left\{v_{1}^{-}, v_{2}^{-}, \ldots, v_{j}^{-}, \ldots, v_{n}^{-}\right\}=\left\{\left(\min _{i} v_{i j} \mid j \in J_{1}\right),\left(\max _{i} v_{i j} \mid j \in J_{2}\right) \mid i=1,2, \ldots, m\right\}
\end{aligned}
$$

where $J_{1}$ is associated with benefit criteria and $J_{2}$ with the cost criteria.

Step 4. Calculate the measures of separation from the positive ideal solution $S_{i}^{*}$ and the negative ideal solution $S_{i}^{-}$: 


$$
\begin{array}{ll}
S_{i}^{*}=\sqrt{\sum_{j=1}^{n}\left(v_{i j}-v_{j}^{*}\right)^{2}}, & i=1,2, \ldots, m \text { and } \\
S_{i}^{-}=\sqrt{\sum_{j=1}^{n}\left(v_{i j}-v_{j}^{-}\right)^{2}}, & i=1,2, \ldots, m
\end{array}
$$

Step 5. Calculation of relative closeness to positive ideal solution $C_{i}^{*}$ which is defined as

$$
C_{i}^{*}=\frac{s_{i}^{-}}{\left(s_{i}^{*}+s_{i}^{-}\right)^{\prime}}, \quad i=1,2, \ldots, m
$$

where $0 \leq C_{i}^{*} \leq 1,\left(C_{i}^{*}=0\right.$ if the alternative $A_{i}$ is equal to negative ideal solution and $C_{i}^{*}=1$ if the alternative $A_{i}$ is equal to positive ideal solution).

Step 6. Rank the preference order (ranking the set of the alternatives by the descending order of the value $C_{i}^{*}$ ).

Based on the algorithms above, weights determination and the ranking results are calculated and presented under section Results and Discussion.

\section{Empirical data and analysis}

As the empirical foundation for evaluating different aspects of living in Central and Eastern European cities, Urban Audit Perception Survey was used in this paper (Statistical Office of the European Union - EUROSTAT, 2015).

Urban Audit represents the Eurostat's statistics on cities that provides information and comparable measurement on a range of socioeconomic aspects that relate to the quality of urban life and living standards in European cities. The coverage of the survey includes several aspects of quality of life, such as demography, housing, health, economic activity, labour market, income disparity, educational qualifications, environment, climate, travel patterns, tourism and cultural infrastructure. The perception survey is a complement to the regular Urban Audit data, presenting how citizens perceive the quality of life in their home cities. This survey has been conducted since 2004, covering 79 European cities, with questions on issues such as employment, the environment, housing, transport, culture, city services and immigration. The survey includes all capital cities, along with between one and six more cities in larger countries, around 500 respondents being interviewed in each city. For the purpose of this paper, the most recent perceptions survey (2015) will be used, including 23 Central and Eastern European Cities (Table 1). 
Table 1: Cities in the sample

\begin{tabular}{|l|l|r|}
\hline \multirow{2}{*}{ Bulgaria } & \multicolumn{1}{|c|}{ City } & Population size \\
\hline \multirow{2}{*}{ Czech Republic } & Sofia & 1055205 \\
\cline { 2 - 3 } & Burgas & 172826 \\
\hline Estonia & Prague & 1077005 \\
\cline { 2 - 3 } Croatia & Ostrava & 282958 \\
\hline Latvia & Tallinn & 336683 \\
\hline Lithuania & Zagreb & 652959 \\
\hline \multirow{5}{*}{ Hungary } & Riga & 423118 \\
\hline \multirow{5}{*}{ Poland } & Vilnius & 453866 \\
& Budapest & 1550299 \\
\cline { 2 - 3 } & Miskolc & 156230 \\
\cline { 2 - 3 } & Warsaw & 1502571 \\
\cline { 2 - 3 } & Kraków & 660046 \\
\cline { 2 - 3 } & Gdansk & 395271 \\
\cline { 2 - 3 } & Bialystok & 255280 \\
\hline Romania & Bucharest & 1718888 \\
\cline { 2 - 3 } & Cluj-Napoca & 276407 \\
\cline { 2 - 3 } & Piatra Neamt & 94807 \\
\hline Slovenia & Ljubljana & 236011 \\
\hline Slovakia & Bratislava & 378952 \\
\cline { 2 - 3 } & Kosice & 199308 \\
\hline Turkey & Ankara & 3812302 \\
\cline { 2 - 3 } & Antalya & 1563934 \\
\cline { 2 - 3 } & Istanbul & 14221482 \\
\hline
\end{tabular}

Source: Eurostat, 2015

The respondents in the selected cities have been interviewed about their overall satisfaction with regard to the cities they live in, but also on their satisfaction with different aspects of urban life: infrastructure and facilities (public transport, health care services, sports, cultural and educational facilities, state of the streets and buildings, public spaces and availability of retail shops). The survey also provides information about citizens' views on employment opportunities, housing situation, integration of foreigners, trust and safety and city administrative services, as well as environmental issues.

On each of these issues, the respondents express their views using one of alternative responses: very satisfied, rather satisfied, rather unsatisfied, not at all satisfied and don't know/no answer. Each response has been assigned a value of the Likert scale (4 for "very satisfied", 1 for "not at all satisfied", while the "don't know/no answer" 
Jelena Stanković et al. • A multi-criteria evaluation of the European cities'smart...

responses are not taken into account). The survey results have been calculated as mean values of the responses. The mentioned aspects of urban living will be used as criterions for assessing the performance of the selected cities. Table 2 presents descriptive statistics of the sample, i.e. the descriptive statistics of the performance matrix for ranking cities (full performance matrix is presented in Appendix, Table A6 and Table A7).

Table 2: Descriptive statistics $(\mathrm{N}=23)$

\begin{tabular}{|c|c|c|c|c|}
\hline Criterion & Mean & St. dev. & Min & Max \\
\hline Satisfied to live in this city & 3.43 & 0.24 & 2.76 & 3.74 \\
\hline Satisfied with the live you lead & 2.06 & 0.19 & 1.70 & 2.37 \\
\hline Public transport & 2.96 & 0.29 & 2.32 & 3.55 \\
\hline Schools & 2.91 & 0.25 & 2.37 & 3.33 \\
\hline Green spaces & 3.02 & 0.28 & 2.40 & 3.54 \\
\hline Sports facilities & 2.84 & 0.26 & 2.41 & 3.19 \\
\hline Cultural facilities & 3.15 & 0.24 & 2.71 & 3.51 \\
\hline Easy to find a good job & 2.31 & 0.40 & 1.54 & 2.98 \\
\hline Foreigners are integrated & 2.78 & 0.33 & 2.03 & 3.29 \\
\hline Easy to find good housing & 2.28 & 0.29 & 1.66 & 2.80 \\
\hline Administrative services & 2.46 & 0.17 & 2.13 & 2.72 \\
\hline Health care services & 2.53 & 0.31 & 2.13 & 3.23 \\
\hline Public spaces & 2.91 & 0.21 & 2.44 & 3.26 \\
\hline Presence of foreigners is good for this city & 3.02 & 0.36 & 2.29 & 3.57 \\
\hline Most people can be trusted & 2.51 & 0.27 & 1.91 & 2.85 \\
\hline $\begin{array}{l}\text { Fight against climate change (e.g. reducing energy } \\
\text { consumption in housing or promoting alternatives to } \\
\text { transport by car) }\end{array}$ & 2.63 & 0.25 & 2.19 & 3.01 \\
\hline Difficulty paying bills & 3.21 & 0.41 & 2.43 & 3.66 \\
\hline State of streets and buildings & 2.65 & 0.25 & 1.99 & 3.16 \\
\hline Availability of retail shops & 3.30 & 0.17 & 3.05 & 3.58 \\
\hline The quality of the air & 2.57 & 0.44 & 1.72 & 3.33 \\
\hline The noise level in the city & 2.59 & 0.30 & 1.87 & 3.06 \\
\hline The cleanliness in the city & 2.69 & 0.33 & 2.04 & 3.23 \\
\hline Feel safe in this city & 2.93 & 0.35 & 2.15 & 3.49 \\
\hline Feel safe in the neighbourhood you live in & 3.14 & 0.22 & 2.64 & 3.57 \\
\hline Trust - people in neighbourhood can be trusted & 2.87 & 0.15 & 2.52 & 3.19 \\
\hline Trust - public administration & 2.51 & 0.19 & 2.12 & 2.79 \\
\hline Personal job situation & 2.16 & 0.18 & 1.87 & 2.51 \\
\hline Financial situation of household & 1.83 & 0.14 & 1.70 & 2.18 \\
\hline
\end{tabular}

Source: Authors' calculations based on Eurostat, 2015 
The overall satisfaction of respondents concerning life in their home cities is described by the first two indicators in Table 2. In 16 out of 23 analyzed cities, over $90 \%$ of the citizens have expressed satisfaction with living in the city (very satisfied and rather satisfied). The highest levels of satisfaction are recorded in Vilnius (98\%), Burgas, Gdansk, Byalistok and Cluj-Napoca (96\%). The least satisfied are citizens of Ankara, Bucharest and Sofia (83\%). These indicators will serve as control criteria, for the purpose of comparing the results of the rankings obtained by assessing multiple criteria.

High levels of satisfaction are expressed regards availability of retail shops (3.30) and ability to pay bills (3.21). The citizens have expressed the low levels of satisfaction regarding the financial situation of their households and personal situations considering employment.

Concerning the views on the most important issues in the city, the citizens have ranked health services, unemployment and road infrastructure as the three top important issues (Table 3).

Table 3: Most important issue in the city (in \%)

\begin{tabular}{|l|l|}
\hline \multicolumn{1}{|c|}{ Most important } & Mean \\
\hline Urban safety & 24.83 \\
\hline Air pollution & 28.48 \\
\hline Noise & 12.21 \\
\hline Public transport & 19.39 \\
\hline Health services & 49.34 \\
\hline Social services & 20.00 \\
\hline Education and training & 27.34 \\
\hline Unemployment & 36.48 \\
\hline Housing conditions & 13.43 \\
\hline Road infrastructure & 32.61 \\
\hline
\end{tabular}

Source: Eurostat, 2015

In addition to data on citizens' perceptions of different categories of urban life, developed model also incorporates the estimation of importance of the criteria. The estimation is provided using pairwise comparisons of criteria, using Saaty's scale (Saaty, 1977). Comparison is performed by authors, based on the sublimation of different approaches in weights assessment in the existing literature. As the starting point for determining the significance of criteria are used expert evaluations available in the previous empirical analyses, as well as the preferences of the inhabitants on the issues that give the greatest importance to life in their cities (e.g. health services and unemployment, as it shown in Table 3). Considering the 
impact of weights on ranking results, the subjective approach in weight coefficients determination is one of the constraints of the research in this paper, but the nature of the problem is such that there is no possibility to apply objective methods (the relevance of entropy results or one of statistical methods such as factor analysis on a sample of 23 units of observation is not adequate).

The pairwise comparison matrix that refers to first level criteria in the model for ranking cities according to perceived smart performance, whose relative importance is to be estimated, is presented in Table 4 .

Table 4: Pairwise comparison matrix for the first level criteria

\begin{tabular}{|c|c|c|c|c|c|}
\hline Criterion & $C_{1}$ & $C_{2}$ & $C_{3}$ & $C_{4}$ & $C_{5}$ \\
\hline$C_{1}$ & 1.00000 & 0.50000 & 4.00000 & 0.20000 & 0.50000 \\
\hline$C_{2}$ & 2.00000 & 1.00000 & 6.00000 & 0.33333 & 1.00000 \\
\hline$C_{3}$ & 0.25000 & 0.16667 & 1.00000 & 0.12500 & 0.20000 \\
\hline$C_{4}$ & 5.00000 & 3.00000 & 8.00000 & 1.00000 & 6.00000 \\
\hline$C_{5}$ & 2.00000 & 1.00000 & 5.00000 & 0.16667 & 1.00000 \\
\hline
\end{tabular}

Source: Authors' calculation

The first part of results refers to determination of criteria importance. For pairwise comparison matrix presented in Table 4, the calculated maximum eigenvalue was $\lambda_{\max }=5.20107963$, as well as the corresponding consistency index $C I=0.050270$ and consistency ratio $C R=0.040540$. The random index value was the one provided by Saaty and Wharton where $R I_{(\mathrm{n}=9)}=1.24$ (data from Table 1. $R I$ (n) values from various authors, Alonso and Lamata, 2001, p. 449). The consistency of estimates given by Table 4 is satisfactory, and the following is the procedure of the AHP method that determines the weight coefficients in the model.

The results i.e. weights are determined using additive normalized decision matrix, as an average value of row coefficients. The additive normalized matrix and determined weights for the first level criteria are presented in Table 5.

Table 5: Additive normalized matrix for the first level criteria

\begin{tabular}{|c|c|c|c|c|c|c|}
\hline Criterion & $C_{1}$ & $C_{2}$ & $C_{3}$ & $C_{4}$ & $C_{5}$ & $w_{j}$ \\
\hline$C_{1}$ & 0.09756 & 0.08824 & 0.16667 & 0.10959 & 0.05747 & 0.10390 \\
\hline$C_{2}$ & 0.19512 & 0.17647 & 0.25000 & 0.18265 & 0.11494 & 0.18384 \\
\hline$C_{3}$ & 0.02439 & 0.02941 & 0.04167 & 0.06849 & 0.02299 & 0.03739 \\
\hline$C_{4}$ & 0.48780 & 0.52941 & 0.33333 & 0.54795 & 0.68966 & 0.51763 \\
\hline$C_{5}$ & 0.19512 & 0.17647 & 0.20833 & 0.09132 & 0.11494 & 0.15724 \\
\hline
\end{tabular}

Source: Authors' calculation 
Analogously, the determination of weights is conducted for all sub-criteria. Pairwise comparison matrices, as well as their consistency measures are presented in the Appendix. The determined weights (on both hierarchical levels) according to AHP algorithm are given in Table 6 . The weights for sub-criteria are generated by multiplying results from Tables A1-A5 by corresponding weight of first level criterion.

Table 6: Relative importance of all criteria and sub-criteria in the model

\begin{tabular}{|c|c|c|c|}
\hline Criterion & Weights & Sub-Criterion & Weights \\
\hline \multirow[t]{3}{*}{$C_{1}$} & \multirow[t]{3}{*}{0.10390} & $C_{11}$ & 0.064756 \\
\hline & & $C_{12}$ & 0.024884 \\
\hline & & $C_{13}$ & 0.014265 \\
\hline \multirow[t]{6}{*}{$C_{2}$} & \multirow[t]{6}{*}{0.18384} & $C_{21}$ & 0.026218 \\
\hline & & $C_{22}$ & 0.077630 \\
\hline & & $C_{23}$ & 0.008927 \\
\hline & & $C_{24}$ & 0.006135 \\
\hline & & $C_{25}$ & 0.046432 \\
\hline & & $C_{26}$ & 0.018495 \\
\hline \multirow[t]{5}{*}{$C_{3}$} & \multirow[t]{5}{*}{0.03739} & $C_{31}$ & 0.002465 \\
\hline & & $\mathrm{C}_{32}$ & 0.001534 \\
\hline & & $C_{33}$ & 0.018183 \\
\hline & & $C_{34}$ & 0.009303 \\
\hline & & $C_{35}$ & 0.005905 \\
\hline \multirow[t]{4}{*}{$C_{4}$} & \multirow[t]{4}{*}{0.51763} & $C_{41}$ & 0.172543 \\
\hline & & $C_{42}$ & 0.086272 \\
\hline & & $C_{43}$ & 0.172543 \\
\hline & & $C_{44}$ & 0.086272 \\
\hline \multirow[t]{8}{*}{$C_{5}$} & \multirow[t]{8}{*}{0.15724} & $C_{51}$ & 0.044763 \\
\hline & & $C_{52}$ & 0.044763 \\
\hline & & $C_{53}$ & 0.005186 \\
\hline & & $C_{54}$ & 0.005186 \\
\hline & & $C_{55}$ & 0.020019 \\
\hline & & $C_{56}$ & 0.008651 \\
\hline & & $C_{57}$ & 0.008651 \\
\hline & & $C_{58}$ & 0.020019 \\
\hline$\Sigma$ & 1.00000 & $\Sigma$ & 1.00000 \\
\hline
\end{tabular}

Source: Authors' calculation according to AHP algorithm

At the level of indicators (Table 6), the most important ones are "easy to find a good job" $\left(C_{41}, w_{41}=0.172543\right)$ and "personal job situation" $\left(C_{43}, w_{43}=0.172543\right)$, followed by indicators from the same group such as "difficulty of paying bills" $\left(C_{42}\right.$, $\left.w_{42}=0.086272\right)$ and "financial situation of the household" $\left(C_{44}, w_{44}=0.086272\right)$. Beside these indicators, as important ones are weighted "schools in the city" 
Jelena Stanković et al. • A multi-criteria evaluation of the European cities'smart...

$\left(C_{22}, w_{22}=0.077630\right)$ and "public transport" $\left(C_{11}, w_{11}=0.064756\right)$. This significance is understandable from the point of view of individuals who assess life in the city through the prism of personal satisfaction of life in that city, and the most important aspects of urban quality are seen through the availability of personal job possibilities, achievement of financial goals and family life comfort.

After determining the significance of all criteria in the model, ranking of cities according to these criteria is performed. Table 7 contains the results of the ranking by using TOPSIS method, compared to the ranking by the perceived satisfaction with life in the city. A measure of perceived life satisfaction in a city was created using two indicators (1) satisfaction with life they lead and (2) satisfaction to live in the observed city, taking into account different aspects of quality of life and assuming they have the same importance, i.e. weights.

Table 7: Ranking results of TOPSIS method

\begin{tabular}{|c|c|c|c|c|c|c|}
\hline \multirow{2}{*}{ City } & \multicolumn{2}{|c|}{$\begin{array}{c}\text { Ranking according } \\
\text { to model }\end{array}$} & \multicolumn{4}{|c|}{ Ranking according to perceived life satisfaction } \\
\hline & Score & Rank & $\begin{array}{c}\text { The life you } \\
\text { lead }\end{array}$ & $\begin{array}{l}\text { You are satisfied to } \\
\text { live in this city }\end{array}$ & Score & Rank \\
\hline Prague & 0.803184 & 1 & 2.161616 & 3.363636 & 2.762626 & 12 \\
\hline Cluj-Napoca & 0.742380 & 2 & 1.970000 & 3.696970 & 2.833485 & 9 \\
\hline Vilnius & 0.730542 & 3 & 2.363636 & 3.720000 & 3.041818 & 1 \\
\hline Tallinn & 0.691245 & 4 & 1.969388 & 3.448980 & 2.709184 & 17 \\
\hline Antalya & 0.625832 & 5 & 2.340000 & 3.610000 & 2.975000 & 3 \\
\hline Warsaw & 0.600722 & 6 & 2.111111 & 3.444444 & 2.777778 & 11 \\
\hline Bratislava & 0.598928 & 7 & 2.090909 & 3.373737 & 2.732323 & 15 \\
\hline Gdansk & 0.572212 & 8 & 2.110000 & 3.640000 & 2.875000 & 4 \\
\hline Sofia & 0.553615 & 9 & 1.696970 & 3.275510 & 2.486240 & 21 \\
\hline Riga & 0.541288 & 10 & 1.888889 & 3.200000 & 2.544444 & 19 \\
\hline Krakow & 0.540081 & 11 & 2.101010 & 3.535354 & 2.818182 & 10 \\
\hline Ankara & 0.529102 & 12 & 2.170000 & 3.290000 & 2.730000 & 16 \\
\hline Burgas & 0.510885 & 13 & 1.949495 & 3.740000 & 2.844747 & 8 \\
\hline Bucharest & 0.501842 & 14 & 1.808081 & 3.214286 & 2.511183 & 20 \\
\hline Ostrava & 0.484880 & 15 & 2.333333 & 3.181818 & 2.757576 & 13 \\
\hline Istanbul & 0.476734 & 16 & 2.080808 & 2.760000 & 2.420404 & 22 \\
\hline Ljubljana & 0.463800 & 17 & 2.370000 & 3.600000 & 2.985000 & 2 \\
\hline Budapest & 0.374064 & 18 & 1.816327 & 3.360000 & 2.588163 & 18 \\
\hline Piatra Neamt & 0.342890 & 19 & 1.909091 & 3.585859 & 2.747475 & 14 \\
\hline Kosice & 0.342295 & 20 & 2.171717 & 3.530612 & 2.851165 & 7 \\
\hline Bialystok & 0.333861 & 21 & 2.130000 & 3.580000 & 2.855000 & 6 \\
\hline Zagreb & 0.322037 & 22 & 2.111111 & 3.600000 & 2.855556 & 5 \\
\hline Miskolc & 0.237197 & 23 & 1.747475 & 3.040404 & 2.393939 & 23 \\
\hline
\end{tabular}

Source: Authors' calculation according to TOPSIS algorithm 
The results indicate that there are no strong relations between city ranking according to smart performances and perceived life satisfaction of citizens. Namely, the best ranked city in TOPSIS model is Prague, with relative closeness to positive ideal solution determined as 0.803184 . At the same time, citizen perception on life satisfaction in Prague is moderate and ranked on $12^{\text {th }}$ position. In a similar way, can be discussed rankings of Tallinn or Cluj-Napoca. The opposite rank reversal appears in the cities such as Ljubljana, Zagreb, Bialystok and Kosice, where ranks according to perceived life satisfaction are much higher than ranks based on composite measures of smart performance.

In order to determine the strength of the relationship between ranks according to TOPSIS model and perceived life satisfaction of inhabitants, a correlation analysis is performed and the results are presented in Table 8 .

Table 8: Correlations results

\begin{tabular}{|c|c|c|c|c|}
\hline \multicolumn{3}{|l|}{ Statistics } & $\begin{array}{l}\text { Ranking } \\
\text { according to } \\
\text { model }\end{array}$ & $\begin{array}{c}\text { Ranking } \\
\text { according to } \\
\text { perceived life } \\
\text { satisfaction }\end{array}$ \\
\hline \multirow[t]{6}{*}{$\begin{array}{l}\text { Spearman's } \\
\text { rho }\end{array}$} & \multirow{3}{*}{$\begin{array}{l}\text { Ranking } \\
\text { according to } \\
\text { model }\end{array}$} & $\begin{array}{l}\text { Correlation } \\
\text { Coefficient }\end{array}$ & 1.000 & 0.146 \\
\hline & & Sig. (2-tailed) & 0.000 & 0.506 \\
\hline & & $\mathrm{N}$ & 23 & 23 \\
\hline & \multirow{3}{*}{$\begin{array}{l}\text { Ranking } \\
\text { according to } \\
\text { perceived life } \\
\text { satisfaction }\end{array}$} & \begin{tabular}{|l|} 
Correlation \\
Coefficient
\end{tabular} & 0.146 & 1.000 \\
\hline & & Sig. (2-tailed) & 0.506 & 0.000 \\
\hline & & $\mathrm{N}$ & 23 & 23 \\
\hline
\end{tabular}

Source: Authors' calculation

The results indicate a weak correlation between the two observed ranks (Spearman's rho is 0.146), which indicates that the research hypothesis has been disproved and that there is no strong coherence between composite measure of city's smart performance and the citizens' direct perceptions on the quality of life.

\section{Results and discussion}

This study provides the ranking results for 23 Central and Eastern European cities according to their smart performances. Additionally, comparison of ranking according to the smart performance in relation to the ranking according to perceived life satisfaction of citizens was performed. As major benefits from such research results recent economic literature has highlighted determination of 
competitive advantages of observed urban areas and identification of key urban problems for future development strategies. This kind of research can be utilised in the ways to provide information about local leaders and successful models of local economic growth and explore the environmental performance of the various urban forms and their role in sustainable local economic development (Yu et al., 2016; Chen et al., 2005; Cassette et al., 2012; Revelli and Tovmo, 2007). Different mathematical and econometrical approaches have been used in previous research studies in order to compare or rank cities from the observed, spatially connected geographical areas, according to different parameters of urban and local economic development.

From methodological aspect, the contribution of the paper can be perceived through the formulation of a new model for ranking cities, which respects the specificities and characteristics of urban development in Central and Eastern Europe. Multicriteria analysis and multi-objective programming are relevant tools for evaluating planning and development of urban and environmental strategies since from the 80s of the last century (Hinloopen et al., 1983; Nijkamp, 1980) and the model developed in this paper represents a step forward in the application of relevant methods.

According to the results relating to determination of the importance of certain groups of smart performances in the model, the most important group of criteria is employment and finance (determined weight 0.51763 ). This result is closely linked to the data on the most important issues in the surveyed cities, where health care and unemployment are the dominant topics (Table 3). In addition to employment and finance, as significant groups of criteria are identified liveability and housing conditions (0.18384) and governance, urban safety, trust and social cohesion (0.15724). The last in order of importance are groups of criteria relating to infrastructure $(0.10390)$ and environment $(0.03739)$. This order of criteria importance clearly indicates that citizens of observed Central and Eastern Europe cities evaluate the success of the urban development process based on solving the unemployment and economic development problems, while less attention is paid to the ecological and social characteristics of urban areas. Also, such results clearly suggest that future local development strategies should focus on unemployment and economic empowerment of the population, as the key problems perceived by inhabitants in CEE cities.

The ranks of cities obtained by using tailor-made multi-criteria model, that present cumulative assessment of five groups of smart performance categories, each comprising several sub-criteria, indicate different results than those based on direct perceptions of citizens on the overall life satisfaction in the city. The top cities according to multi-criteria model are Prague, Cluj-Napoca, Vilnius and Tallinn. Comparing the ranks clearly indicates a weak relation between high level of smart performance and perceived satisfaction with life in the observed city. Only a few 
cities have high ranks on both grounds (such as Vilnius which is third by smart performance and the first by perceived satisfaction with life in the city) or low ranks (e.g. Miskolc, Budapest). The obtained results, for this group of cities, indicate that there is no clear connection between the perception of a higher level of fulfilment of the smart performances in the city and the quality of life in this city. From the above, the hypothesis tested in the paper is disproved. The explanation for this lack of coherence can be found in the fact that, still in CEE the most important urban development topics are health services, unemployment and road infrastructure. Simply, economic aspects are still dominant in the perception of urban development in CEE, while the population of these cities considerably less pay attention and appreciates social and environmental aspects.

\section{Conclusion}

As the main objective of the paper was to investigate the relation between multiple aspects of urban life, conceptualized within the smart city framework, and subjective perceptions of citizens' quality of life, we have attempted to establish the link between a composite measure of cities' smart performance and subjective perceptions of citizens' life satisfaction. The findings of our study imply that direct perceptions of citizens on the overall life satisfaction in the analyzed European cities are not influenced by their smart performance. The comparison of ranks obtained by the constructed multi-criteria model and perceived satisfaction of life indicates a rather weak relation.

The paper contributes to the empirical literature on the ranking of cities based on various location-specific amenities. Depending on different objectives, methods, chosen indicators and assigned weights, the results of previous empirical investigations are rather ambiguous. We propose a novel approach in constructing the composite measure that captures various aspects of urban life with different relative importance, by combining the Analytical Hierarchy Process with standard multi-criteria procedures. The findings of the performed procedures allow useful comparisons between the cities' competitiveness levels obtained based on a number of weighted criteria, with unconditional rankings based on subjective perceptions. Furthermore, our study contributes to the efforts of evaluating the quality of life grounded on location-specific subjective data on well-being.

Our research faces the usual limitations regarding the usage of data on selfreported life satisfaction and subjective evaluations provided by the respondents. The study could be extended in a variety of directions, the most important one being to complement the analysis including a number of objective indicators of cities' performance, such as data on cities' labour markets, density of economic units, climate specifications, public transport networks, etc. Also, to allow a 
more sophisticated decomposition of the main categories into sub-indicators, the implementation of alternative methods could be considered.

The research aims to contribute to better understanding of the challenges faced by modern urban areas, offering some empirical implications of city rankings for creating urban governance policies and programs. The city rankings based on various indicators enable informative comparisons of the areas that determine the cities' competitive position in the attempt to attract business and educated workforce. The positioning of the cities is the first step in identifying priorities in urban development strategies. Our findings indicate that quality of life rankings can be useful as a basis for intervention and improvement, but that citizens from different areas have different priorities regarding economic, social, political or environmental aspects of living. These rankings could serve policymakers as informative grounds to identify potentials that can be developed, and then translate them into policies that would affect citizens' quality of life. Since the citizens of CEE put economic aspects to the fore of their life quality assessments, urban development strategies should be aimed at contributing to economic growth and employment.

\section{References}

Alawadhi, S. et al. (2012) "Building understanding of smart city initiatives". In Scholl, H. J., Janssen, M., Wimmer, M.A., Moe, C.E., Flak, L.S. eds., EGOV 2012, Lecture Notes in Computer Science, Vol 7443, pp. 40-53.

Albino, V., Berardi, U., Dangelico, R.M. (2015) "Smart cities: Definitions, dimensions, performance, and initiatives", Journal of Urban Technology, Vol. 22, No. 1, pp. 3-21, doi: 10.1080/10630732.2014.942092.

Alonso, J.A., Lamata, M.T. (2006) "Consistency in the Analytic Hierarchy Process: A New Approach", International Journal of Uncertainty, Fuzziness and Knowledge-Based Systems, Vol. 14, No.4, pp. 445-459, doi: 10.1142/ $\mathrm{S} 0218488506004114$.

Angelidou, M. (2014) "Smart city policies: A spatial approach”, Cities, Vol. 41, pp. S3-S11, doi: 10.1016/j.cities.2014.06.007.

Aurigi, A. (2005) Making the Digital City: The Early Shaping of Urban Internet Space, Farnborough: Ashgate, doi: 10.4324/9781315249964.

Batty, M. et al. (2012) "Smart cities of the future", The European Physical Journal, Vol. 214, pp. 481-518, doi: 10.1140/epjst/e2012-01703-3.

Berger, M.C., Blomquist, G.C., Sabirianova, P.K. (2008) "Compensating differentials in emerging labor and housing markets: estimates of quality of life in Russian cities", Journal of Urban Economics, Vol. 63, No. 1, pp. 25-55, doi: 10.1016/j.jue.2007.01.006. 
Berst, J. et al. (2013) "Smart Cities Readiness Guide", [Internet]. Available at: http://smartcitiescouncil.com/resources/smart-cities-readiness-guide [Accessed: May 30, 2016].

Bibri, S.E. (2017) "Smart sustainable cities of the future: An extensive interdisciplinary literature review", Sustainable Cities and Society, Vol. 31, pp. 183-212, doi: 10.1016/j.scs.2017.02.016.

Caragliu, A., Del Bo, C., Nijkamp, P. (2011) "Smart cities in Europe", Journal of Urban Technology, Vol. 18, No. 2, pp. 65-82, doi: 10.1080/10630732.2011.601117.

Cassette, A., Di Porto, E., Foremny, D. (2012) "Strategic fiscal interaction across borders: evidence from French and German local governments along the Rhine Valley", Journal of Urban Economics, Vol. 72, pp. 17-30, doi: 10.1016/j. jue.2011.12.003.

Chen, Y., Li, H., Zhou, L.A. (2005) "Relative performance evaluation and the turnover of provincial leaders in China", Economics Letters, Vol. 88, pp. 421425, doi: 10.1016/j.econlet.2005.05.003.

Chourabi, H. et al. (2012) "Understanding smart cities: An integrative framework". In The $45^{\text {th }}$ Hawaii international conference on system science (HICSS), pp. 2289-2297, doi: 10.1109/hicss.2012.615.

Dameri, R., Cocchia, A. (2013) "Smart city and digital city: Twenty years of terminology evolution", X conference of the Italian chapter of AIS, ITAIS 2013.

Del Bo, C., Florio, M. (2008) "Infrastructure and growth in the European Union: an empirical analysis at the regional level in a spatial framework". Departmental Working Papers 2008-37, Milan: University of Milan, Department of Economics.

Economist Intelligence Unit (2013) Hot Spots 2025: Benchmarking the Future Competitiveness of Cities. [Internet]. Available at: http://www.citigroup.com/ citi/citiforcities/ pdfs/hotspots2025.pdf. [Accessed: May 30, 2016].

Florida, R.L. (2002) The rise of the creative class: and how it's transforming work, leisure, community and everyday life, New York: Basic Books.

Forman E.H., Gass S.I. (2001) "The Analytic Hierarchy Process - An Exposition", Operations Research, Vol. 49, No.4, pp. 469-486, doi: 10.1287/opre.49.4.469.11231.

Frey, B.S., Stutzer, A. (2008) "Stress that doesn't pay: the commuting paradox", Scandinavian Journal of Economics, Vol. 110, No. 2, pp. 339-366, 10.1111/j.1467-9442.2008.00542.x.

Frobenius, F.G. (1912) Uber Matrizen aus nicht negativen Elementen, S.B. Preuss Acad. Wiss. Berlin, 456-477, doi: 10.3931/e-rara-18865.

Galán-García, J.L., Aguilera-Venegas, G., Rodríguez-Cielos, P. (2014) "An accelerated-time simulation for traffic flow in a smart city", Journal of Computational and Applied Mathematics, Vol. 270, pp. 557-563, doi: 10.1016/j. cam.2013.11.020.

Giffinger, R., Fertner, C., Kramar, H., Meijers, E. (2007) Smart cities ranking of European medium-sized cities. Vienna: Centre of Regional Science. 
Glaeser, E.L., Berry, C.R. (2006) Why are smart places getting smarter? Taubman Centre Policy Brief 2006-2, Cambridge MA: Taubman Centre.

Heller, P. (2013) Civil Society and Social Movements in a Globalizing World: Challenges and Opportunities. Human Development Report Occasional Papers, United Nations Development Agency.

Hinloopen E., Nijkamp P., Rietveld P. (1983) "Qualitative discrete multiple criteria choice models in regional planning", Regional Science and Urban Economics, Vol. 13, No. 1, pp. 77-102, doi: 10.1016/0166-0462(83)90006-6.

Hollands, R.G. (2008) “Will the real smart city please stand up?", City, Vol. 12, No. 3, pp. 303-320, doi: 10.1080/13604810802479126.

International Telecommunication Union ITU (2014) Smart sustainable cities: An analysis of definitions. ITU-T Focus Group on Smart Sustainable Cities 10/2014.

Kearney, A.T. (2015) "Global Cities Index and Emerging Cities Outlook: Global Cities, Present and Future", [Internet]. Available at: https://www.atkearney.com/ documents/10192/5911137/Global+Cities+201+-+The+Race+Accelerates. pdf/7b239156-86ac-4bc6-8f30-048925997ac4 [Accessed: May 30, 2016].

Khan, Z. et al. (2015) "Towards cloud based big data analytics for smart future cities", Journal of Cloud Computing Advances, Systems and Applications, Vol. 4, No. 2, doi: 10.1186/s13677-015-0026-8.

Kitchin, R. (2013) "The real-time city? Big data and smart urbanism", Geo Journal, Vol. 79, pp. 1-14, doi: 10.1007/s10708-013-9516-8.

Komninos. N. (2002) Intelligent cities: innovation, knowledge systems and digital spaces, London: Spon Press.

Kourtit, K., Nijkamp, P., Arribas, D. (2012) "Smart cities in perspective - a comparative European study by means of self-organizing maps", Innovation: The European Journal of Social Science Research, Vol. 25, No. 2, pp. 229-246, doi: 10.1080/13511610.2012.660330.

Lee, J.H., Phaal, R., Lee, S.H. (2013) “An integrated service-device-technology roadmap for smart city development". Technological Forecasting and Social Change, Vol. 80, No. 2, pp. 286-306, doi: 10.1016/j.techfore.2012.09.020.

Leskinen, P. (2000) "Measurement scales and scale independence in the Analytic Hierarchy Process", Journal of Multi-Criteria Decision Analysis, Vol. 9, pp. 163174, doi: 10.1002/1099-1360(200007)9:4<163::AID-MCDA274>3.0.CO;2-L.

Liu, B.C. (1977) "Quality of life indicators in U.S. Metropolitan Areas", Social Indicators Research, Vol. 4, No. 1, pp. 107-114, doi: 10.1007/bf00353126.

Lombardi, P. et al. (2011) "An advanced triple-helix network model for smart cities performance". In Regional Development: Concepts, Methodologies, Tools, and Applications, doi: 10.4018/978-1-4666-0882-5.ch808.

Ma, J., Zhang, Q. (1991) "9/9-9/1 scale method of the AHP”, Proceedings of 2nd International Symposium on the AHP, Vol. 1, pp. 197-202. Pittsburgh, USA: RWS Publications. 
Marsal-Llacuna, M.L., Colomer-Llinàs, J., Meléndez-Frigola, J. (2015) "Lessons in urban monitoring taken from sustainable and livable cities to better address the Smart Cities initiative", Technological Forecasting and Social Change, Vol. 90, pp. 611-622, doi: 10.1016/j.techfore.2014.01.012.

Mori Memorial Foundation, Institute for Urban Strategies (2015) Global Power City Index: Yearbook 2015. Japan: Mori Memorial Foundation.

Mullen, E. J. (2014) "Evidence-based knowledge in the context of social practice", Scandinavian Journal of Public Health, Vol. 42, No. 13, pp. 59-73, doi: 10.1177/1403494813516714.

Neirotti, P. et al. (2014) "Current trends in smart city initiatives - some stylized facts", Cities, Vol. 38, pp. 25-36, doi: 10.1016/j.cities.2013.12.010.

Nijkamp, P. (1980) Environmental policy analysis, Wiley: Chichester/New York.

Nordhaus, W.D., Tobin, J. (1972) Is growth obsolete? In Economic research: Retrospect and Prospect, Vol. 5. New York, Columbia University Press.

Odendaal, N. (2003) "Information and Communication Technologies (ICTs) and local governance: Understanding the differences between cities in developed and emerging economies", Computers, Environment and Urban Systems, Vol. 27, pp. 585-607, doi: 10.1016/s0198-9715(03)00016-4.

Piro, G. et al. (2014) "Information centric services in smart cities", The Journal of Systems and Software, Vol. 88, pp. 169-188, doi: 10.1016/j.jss.2013.10.029.

Perron, O. (1907) „Zur Theorie der Matrizen“, Math. Annales, Vol. 64, pp. 248-263.

PricewaterhouseCoopers (2014) Cities of Opportunity 6. [Internet]. Available at: http://www.pwc.com/us/en/cities-ofopportunity/2014/pdf-download.jhtml. [Accessed: May 30, 2016].

Revelli, F., Tovmo, P. (2007) "Revealed yardstick competition: Local government efficiency patterns in Norway", Journal of Urban Economics, Vol. 62, No.1, pp. 121-134, doi: 10.1016/j.jue.2006.11.004.

Roback, J. (1982) "Wages, rents and the quality of life", Journal of Political Economy, Vol. 90, No. 6, pp. 1257-1278, doi: 10.1086/261120.

Rosen, S. (1979) "Wages-based indexes of urban quality of life". In Mieszkowski, P., Straszheim, M. eds., Current Issues in Urban Economics, Baltimore: John Hopkins University Press.

Saaty, T.L. (1994) Fundamentals of Decision Making and Priority Theory with the Analytic Hierarchy Process, Pittsburgh, PA: RWS Publications.

Saaty, T.L. (1980) Multicriteria decision making: the Analytic Hierarchy Process. New York, NY: McGraw-Hill.

Saaty, T.L. (1977) "A scaling method for priorities in hierarchical structures", Journal of Mathematical Psychology, Vol. 15, pp. 234-281, doi: 10.1016/00222496(77)90033-5. 
Sauer, S.C. (2012) "Do smart cities produce smart entrepreneurs?", Journal of Theoretical and Applied Electronic Commerce Research, Vol. 7, No. 3, pp. 6373, doi: 10.4067/s0718-18762012000300007.

Shapiro, J. M. (2006) "Smart cities: Quality of life, productivity, and the growth effects of human capital", Review of Economics and Statistics, Vol. 88, No. 2, pp. 324-335, doi: 10.1162/rest.88.2.324.

Statistical Office of the European Union EUROSTAT (2015) Urban Audit database. Available at: http://ec.europa.eu/eurostat/data/database [Accessed: May 30, 2016].

Thurstone, L. L. (1927) "A law of comparative judgements", Psychological Reviews, Vol. 34, pp. 273-286.

Thuzar, M. (2011) "Urbanization in South East Asia: Developing Smart Cities for the Future?," Regional Outlook, pp. 96-100.

Townsend, A. (2013). Smart cities - big data, civic hackers and the quest for a new utopia. New York: Norton \& Company.

Vanolo, A. (2014) "Smartmentality: The Smart City as Disciplinary Strategy", Urban Studies, Vol. 51, No. 5, pp. 883-898, doi: 10.1177/0042098013494427.

Vienna University of Technology Department of Spatial Planning and SRF - Centre of Regional Science (2015) Europeansmartcities4.0. [Internet]. Available at: http://www.smart-cities.eu/?cid=-1 andver=4 [Accessed: $30^{\text {th }}$ May 2016].

Walravens, N. (2012) "Mobile business and the smart city: Developing a business model framework to include public design parameters for mobile city services", Journal of Theoretical and Applied Electronic Commerce Research, Vol. 7, No. 3, pp. 121-135, doi: 10.4067/S0718-18762012000300011.

Washburn, D. et al. (2010) Helping CIOs Understand 'Smart City' Initiatives: Defining the Smart City, its Drivers, and the Role of the CIO, Cambridge, MA: Forrester Research.

Welsch, H. (2006) "Environment and happiness: valuation of air pollution using life satisfaction data", Ecological Economics, Vol. 58, No. 4, pp. 801-813, doi: 10.1016/j.ecolecon.2005.09.006.

Yoon, K., Hwang, C.L. (1995) Multiple Attribute Decision Making: An Introduction, Sage Publications: London.

Yu, J., Zhou L.A., Zhu G. (2016) "Strategic interaction in political competition: Evidence from spatial effects across Chinese cities", Regional Science and Urban Economics, Vol. 57, pp. 23-37, doi: 10.1016/j.regsciurbeco.2015.12.003. 
Višekriterijska evaluacija pametnih performansi europskih gradova: gospodarski, socijalni i okolišni aspekti

Jelena Stanković ${ }^{1}$, Marija Džunić ${ }^{2}$, Željko Džunić $^{3}$, Srđan Marinković ${ }^{4}$

\section{Sažetak}

Svrha rada je rangirati gradove srednje i istočne Europe na temelju različitih elemenata pametnih performansi gradova. Ova analiza omogućuje procjenu društvenih, ekonomskih $i$ ekoloških aspekata urbanog života, koji predstavljaju odrednice konkurentnosti gradova, a time i pozicije na rang listi. Istraživanje se temelji na podacima o percepciji građana o različitim aspektima urbane kvalitete, koje pruža Eurostatova baza Urban Audit Perception Survey. Za procjenu raznih hijerarhijski strukturiranih pokazatelja pametnih performansi gradova, razvijen je višekriterijski model analize koji kombinira metodu Analitički hijerarhijski proces (Analytic Hierarchy Process - AHP) za određivanje relativne važnosti kriterija $i$ TOPSIS (Technique for Order Preference by Similarity to Ideal Solution) metodu rangiranja. Glavni nalaz rada sugerira da izravna percepcija građana o cjelokupnom životnom zadovoljstvu $u$ analiziranim europskim gradovima nije uvjetovana "pametnim" performansama gradova. Usporedba poretka dobivenih konstruiranim višekriterijskim modelom i percipiranog zadovoljstva života ukazuje na njihov prilično slab odnos.

Ključne riječi: pametni gradovi, urbani razvoj, višekriterijska analiza, održivost, infrastruktura

JEL klasifikacija: $C 44, O 18$

${ }^{1}$ Izvanredna profesorica, Sveučilište u Nišu, Ekonomski fakultet, Trg Kralja Aleksandra 11, 18000 Niš, Srbija. Znanstveni interes: kvantitativna ekonomija. Tel.: +381 18528 655. E-mail: jelena.stankovic@eknfak.ni.ac.rs (osoba za kontakt).

${ }^{2}$ Izvanredna profesorica, Sveučilište u Nišu, Ekonomski fakultet, Trg Kralja Aleksandra 11, 18000 Niš, Srbija, Znanstveni interes: politička ekonomija. Tel.: +381 18528 683. E-mail: marija_dzunic@ni.ac.rs.

${ }^{3}$ IT konzultant, Sveučilište u Nišu, JUNIS, Univerzitetski trg 2, 18000 Niš, Srbija. Znanstveni interes: informacijski sustavi.Tel.: +38162445 307.E-mail:z.dzunic@ni.ac.rs.

${ }^{4}$ Redoviti profesor, Sveučilište u Nišu, Ekonomski fakultet, Trg Kralja Aleksandra 11, 18000 Niš, Srbija. Znanstveni interes: financije i bankarstvo. Tel.: +381 18528 604. E-mail: srdjan. marinkovic@eknfak.ni.ac.rs. 
Jelena Stanković et al. • A multi-criteria evaluation of the European cities'smart...

\section{Appendices}


Jelena Stanković et al. • A multi-criteria evaluation of the European cities'smart...

Table A1: Pairwise comparison matrix for the sub-criteria under Infrastructure

\begin{tabular}{|c|c|c|c|c|}
\hline Sub-criteria & $C_{11}$ & $C_{12}$ & $C_{13}$ & $w_{\mathrm{j}}$ \\
\hline$C_{11}$ & 1.00000 & 3.00000 & 4.00000 & 0.62322 \\
\hline$C_{12}$ & 0.33333 & 1.00000 & 2.00000 & 0.23949 \\
\hline$C_{13}$ & 0.25000 & 0.50000 & 1.00000 & 0.13729 \\
\hline
\end{tabular}

$\mathrm{CI}=0.009169, \mathrm{CR}=0.015808$

Source: Authors' calculation

Table A2: Pairwise comparison matrix for the sub-criteria under Liveability and Housing

\begin{tabular}{|c|c|c|c|c|c|c|c|}
\hline Sub-criteria & $C_{21}$ & $C_{22}$ & $C_{23}$ & $C_{24}$ & $C_{25}$ & $C_{26}$ & $w_{\mathrm{j}}$ \\
\hline$C_{21}$ & 1.00000 & 0.33333 & 3.00000 & 4.00000 & 0.50000 & 2.00000 & 0.14262 \\
\hline$C_{22}$ & 3.00000 & 1.00000 & 7.00000 & 8.00000 & 3.00000 & 5.00000 & 0.42227 \\
\hline$C_{23}$ & 0.33333 & 0.14286 & 1.00000 & 2.00000 & 0.14286 & 0.33333 & 0.04856 \\
\hline$C_{24}$ & 0.25000 & 0.12500 & 0.50000 & 1.00000 & 0.12500 & 0.25000 & 0.03337 \\
\hline$C_{25}$ & 2.00000 & 0.33333 & 7.00000 & 8.00000 & 1.00000 & 3.00000 & 0.25257 \\
\hline$C_{26}$ & 0.50000 & 0.20000 & 3.00000 & 4.00000 & 0.33333 & 1.00000 & 0.10061 \\
\hline
\end{tabular}

$\mathrm{CI}=0.040930, \mathrm{CR}=0.033008$

Source: Authors' calculation

Table A3: Pairwise comparison matrix for the sub-criteria under Environment

\begin{tabular}{|c|c|c|c|c|c|c|}
\hline Sub-criteria & $C_{31}$ & $C_{32}$ & $C_{33}$ & $C_{34}$ & $C_{35}$ & $w_{\mathrm{j}}$ \\
\hline$C_{31}$ & 1.00000 & 2.00000 & 0.16667 & 0.20000 & 0.33333 & 0.06593 \\
\hline$C_{32}$ & 0.50000 & 1.00000 & 0.12500 & 0.16667 & 0.20000 & 0.04103 \\
\hline$C_{33}$ & 6.00000 & 8.00000 & 1.00000 & 3.00000 & 4.00000 & 0.48630 \\
\hline$C_{34}$ & 5.00000 & 6.00000 & 0.33333 & 1.00000 & 2.00000 & 0.24881 \\
\hline$C_{35}$ & 3.00000 & 5.00000 & 0.25000 & 0.50000 & 1.00000 & 0.15793 \\
\hline
\end{tabular}

$\mathrm{CI}=0.037967, \mathrm{CR}=0.033899$

Source: Authors' calculation

Table A4: Pairwise comparison matrix for the sub-criteria under Employment and Finance

\begin{tabular}{|c|c|c|c|c|c|}
\hline Sub-criteria & $C_{41}$ & $C_{42}$ & $C_{43}$ & $C_{44}$ & $w_{\mathrm{j}}$ \\
\hline$C_{41}$ & 1.00000 & 2.00000 & 1.00000 & 2.00000 & 0.33333 \\
\hline$C_{42}$ & 0.50000 & 1.00000 & 0.50000 & 1.00000 & 0.16667 \\
\hline$C_{43}$ & 1.00000 & 2.00000 & 1.00000 & 2.00000 & 0.33333 \\
\hline$C_{44}$ & 0.50000 & 1.00000 & 0.50000 & 1.00000 & 0.16667 \\
\hline
\end{tabular}

$\mathrm{CI}=0.000000, \mathrm{CR}=0.000000$

Source: Authors' calculation 
Table A5: Pairwise comparison matrix for the sub-criteria under Government, Urban Safety and Trust

\begin{tabular}{|c|c|c|c|c|c|c|c|c|c|}
\hline Sub-criteria & $C_{51}$ & $C_{52}$ & $C_{53}$ & $C_{54}$ & $C_{55}$ & $C_{56}$ & $C_{57}$ & $C_{58}$ & $w_{\mathrm{j}}$ \\
\hline$C_{51}$ & 1 & 1 & 7 & 7 & 3 & 5 & 5 & 3 & 0.28468 \\
\hline$C_{52}$ & 1 & 1 & 7 & 7 & 3 & 5 & 5 & 3 & 0.28468 \\
\hline$C_{53}$ & 0.1429 & 0.1429 & 1 & 1 & 0.25 & 0.5 & 0.50 & 0.25 & 0.03298 \\
\hline$C_{54}$ & 0.1429 & 0.1429 & 1 & 1 & 0.25 & 0.5 & 0.5 & 0.25 & 0.03298 \\
\hline$C_{55}$ & 0.3333 & 0.3333 & 4 & 4 & 1 & 3 & 3 & 1 & 0.12732 \\
\hline$C_{56}$ & 0.2 & 0.2 & 2 & 2 & 0.3333 & 1 & 1 & 0.3333 & 0.05502 \\
\hline$C_{57}$ & 0.2 & 0.2 & 2 & 2 & 0.3333 & 1 & 1 & 0.3333 & 0.05502 \\
\hline$C_{58}$ & 0.3333 & 0.3333 & 4 & 4 & 1 & 3 & 3 & 1 & 0.12732 \\
\hline
\end{tabular}

$\mathrm{CI}=0.01673497, \mathrm{CR}=0.01186877$

Source: Authors' calculation 
Jelena Stanković et al. • A multi-criteria evaluation of the European cities'smart...

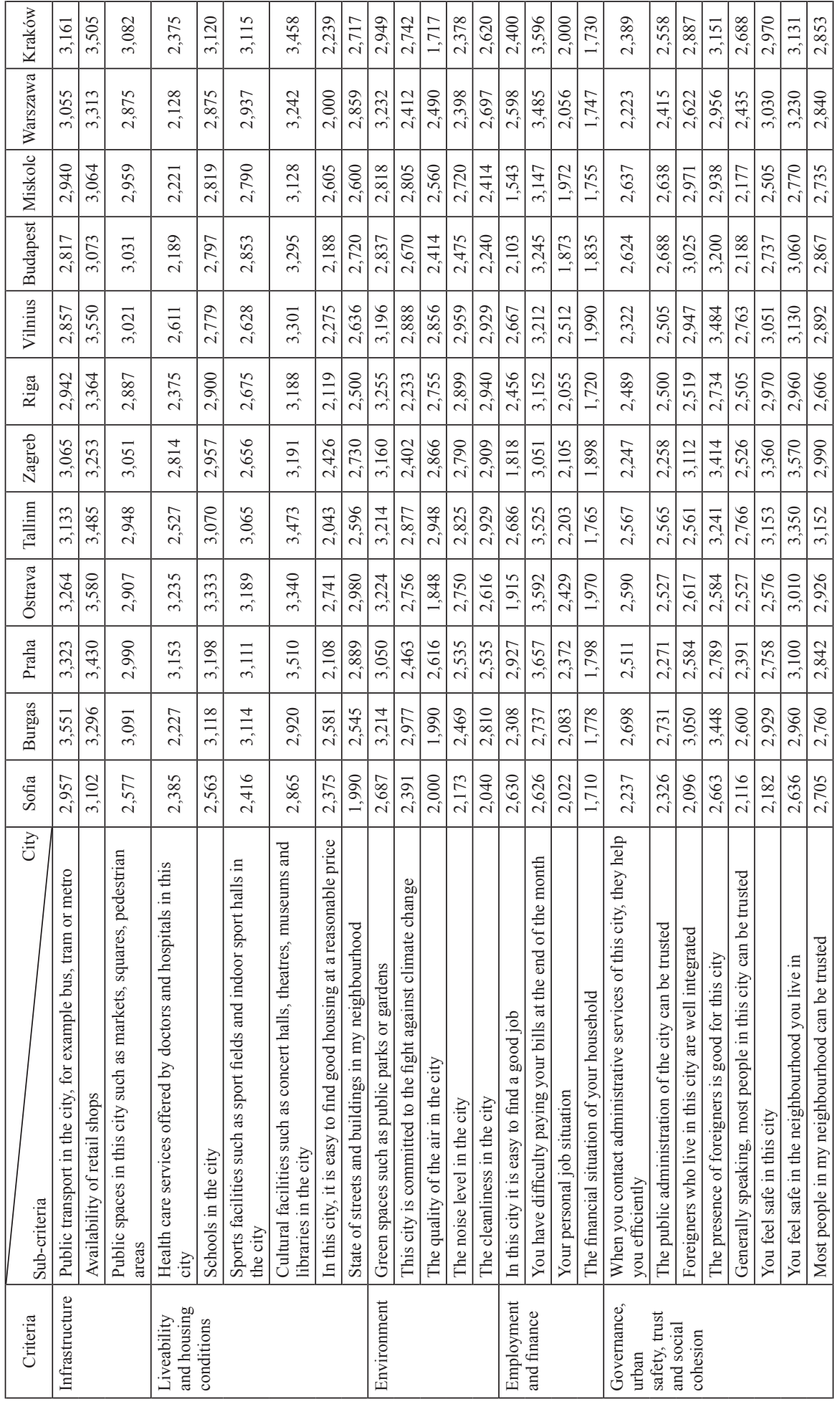


Jelena Stanković et al. • A multi-criteria evaluation of the European cities'smart...

\begin{tabular}{|c|c|c|c|c|c|c|c|c|c|c|c|c|c|c|c|c|c|c|c|c|c|c|c|c|c|c|}
\hline \multicolumn{8}{|c|}{ 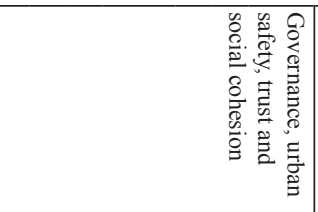 } & \multicolumn{4}{|c|}{ 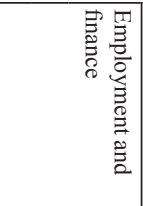 } & \multicolumn{5}{|c|}{ 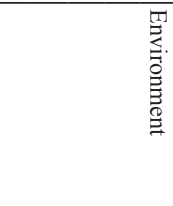 } & \multicolumn{6}{|c|}{ 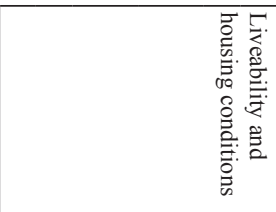 } & \multicolumn{3}{|c|}{ 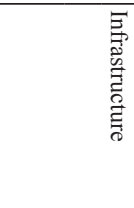 } & : \\
\hline 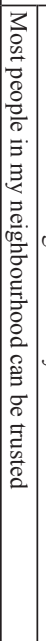 & 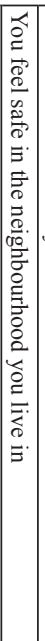 & 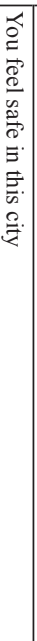 & 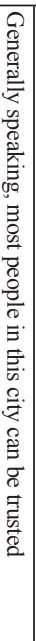 & 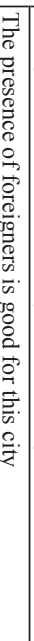 & 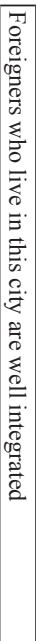 & 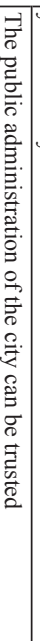 & 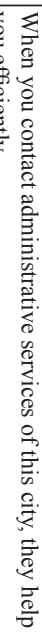 & 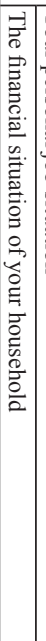 & 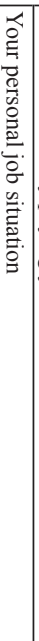 & 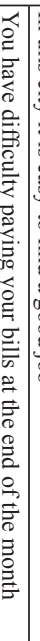 & 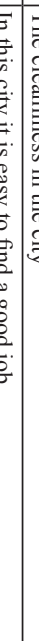 & & & & 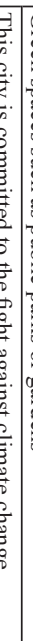 & & 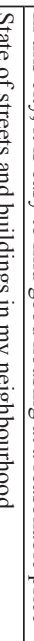 & 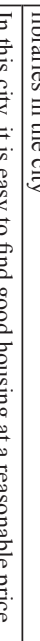 & 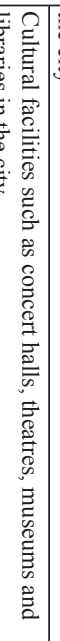 & 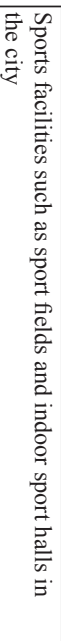 & 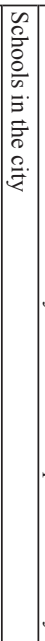 & 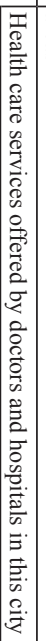 & 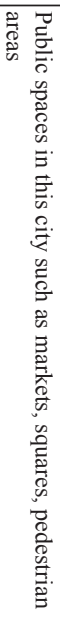 & 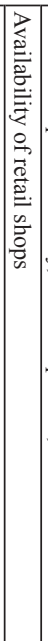 & 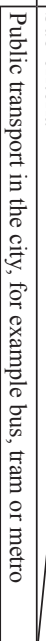 & 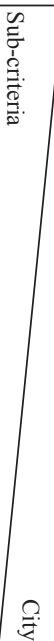 \\
\hline \begin{tabular}{|c|}
$\tilde{N}$ \\
0 \\
$\tilde{D}$ \\
$\Omega$
\end{tabular} & 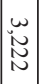 & $\begin{array}{l}\omega \\
\vec{w} \\
\vec{\sigma}\end{array}$ & 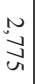 & 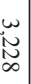 & $\begin{array}{c}N \\
\infty \\
\infty \\
\infty \\
\infty\end{array}$ & 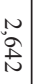 & $\begin{array}{l}\stackrel{n}{ \pm} \\
\stackrel{\star}{\sigma}\end{array}$ & $\stackrel{\vec{c}}{\vec{z}}$ & 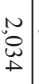 & 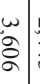 & E: & د. & & | & o & 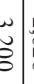 & 6 & 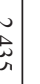 & $\stackrel{⿱ ⺌}{\stackrel{N}{v}}$ & 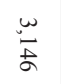 & 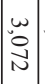 & \begin{tabular}{|c|} 
\\
$\tilde{w}$ \\
0 \\
$N$ \\
$N$
\end{tabular} & $\begin{array}{l}w \\
\ddot{O} \\
\stackrel{0}{0}\end{array}$ & 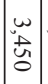 & $\mid \begin{array}{l}\omega \\
\stackrel{\sim}{*} \\
\sigma\end{array}$ & 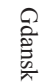 \\
\hline$\left|\begin{array}{l}N \\
0 \\
0 \\
\infty \\
\infty\end{array}\right|$ & $\mid \begin{array}{l}w \\
w \\
w \\
\Delta \\
0\end{array}$ & 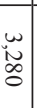 & 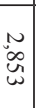 & 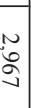 & $\mid \begin{array}{l}\tilde{n} \\
\alpha \\
\sigma \\
\sigma\end{array}$ & $\begin{array}{l}\tilde{N} \\
a \\
\vec{A}\end{array}$ & 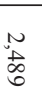 & 品 & $\left|\begin{array}{l}\vec{b} \\
\vec{u} \\
u\end{array}\right|$ & 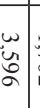 & 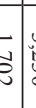 & & s. & \begin{tabular}{|}
$\omega_{\omega}$ \\
$\omega$ \\
\end{tabular} & 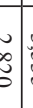 & $\begin{array}{c}\omega \\
\omega \\
w\end{array}$ & $\vec{s}$ & 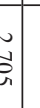 & $\underset{\underset{\sim}{\sim}}{\stackrel{\sim}{\sim}}$ & 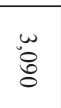 & $\begin{array}{l}\omega \\
\vdots \\
\tilde{N} \\
\infty\end{array}$ & 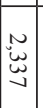 & $\stackrel{\omega}{\sigma}$ & $\mid \begin{array}{l}\omega \\
\stackrel{1}{*} \\
\vec{b} \\
0\end{array}$ & \begin{tabular}{|l|}
$w$ \\
$\tilde{N}$ \\
0 \\
0
\end{tabular} & 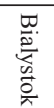 \\
\hline $\mid \begin{array}{c}\tilde{N} \\
\tilde{N} \\
\end{array}$ & $\mid \begin{array}{l}\tilde{N} \\
\dot{b} \\
0\end{array}$ & 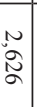 & $\begin{array}{l}\tilde{N} \\
\tilde{\Xi} \\
\tilde{\Xi}\end{array}$ & $\begin{array}{c}w \\
\sim \\
+\end{array}$ & $\mid \begin{array}{l}n \\
0 \\
0 \\
A\end{array}$ & 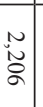 & $\begin{array}{r}\tilde{U} \\
\tilde{U}\end{array}$ & 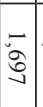 & 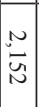 & 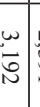 & $\begin{array}{l}0 \\
0 \\
0\end{array}$ & & S. & & $\begin{array}{c}\vec{w} \\
\mathbb{\infty}\end{array}$ & مू & $\vec{E}$ & | & $\begin{array}{l}\tilde{N} \\
\stackrel{\sim}{0} \\
\infty \\
\infty\end{array}$ & $\begin{array}{l}N \\
\stackrel{N}{\infty} \\
\infty \\
\infty\end{array}$ & 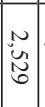 & $\mid \begin{array}{l}\sim \\
\tilde{N} \\
\omega \\
\omega\end{array}$ & 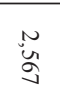 & $\begin{array}{c}\omega \\
\dot{\omega} \\
\sigma\end{array}$ & 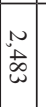 & 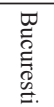 \\
\hline 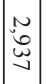 & $\mid \begin{array}{l}w \\
\dot{w} \\
\tilde{\partial}\end{array}$ & 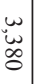 & $\begin{array}{l}N \\
\infty \\
\infty \\
\stackrel{N}{N}\end{array}$ & $w_{i}^{w}$ & $\mid \begin{array}{c}\underset{\sim}{\sim} \\
\substack{\infty \\
\infty}\end{array}$ & $\stackrel{N}{\stackrel{N}{\Xi}}$ & $\stackrel{\sim}{\stackrel{N}{b}}$ & 它 & 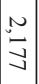 & $\begin{array}{l}\omega \\
: \\
\mathbb{C}\end{array}$ & $\begin{array}{ll}0 \\
0 \\
0 \\
\infty\end{array}$ & U & 5 & $\tilde{s}$ & $\infty$ & $\begin{array}{l}\text { Nu } \\
\infty \\
\infty \\
\infty\end{array}$ & مّ & है & $\stackrel{\omega}{\omega}$ & $\stackrel{\omega}{\stackrel{\omega}{\sim}}$ & \begin{tabular}{|l|}
$\omega$ \\
$\ddot{\delta}$
\end{tabular} & 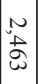 & 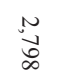 & 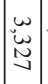 & $\begin{array}{l}w \\
\dot{0} \\
\dot{\alpha} \\
u \\
\sim\end{array}$ & 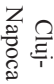 \\
\hline $\mid \begin{array}{l}\tilde{N} \\
\stackrel{0}{\sigma} \\
\sim\end{array}$ & $\begin{array}{l}w \\
\tilde{N} \\
\tilde{c}\end{array}$ & $\underset{\substack{N \\
N}}{\sim}$ & $\begin{array}{c}\stackrel{N}{\sim} \\
\stackrel{\infty}{\sim} \\
\sim \\
\sim\end{array}$ & $\omega_{ \pm}^{\omega}$ & 岕 & 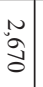 & 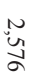 & 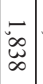 & 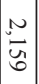 & 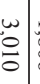 & $\begin{array}{l}\vec{b} \\
0 \\
0\end{array}$ & 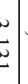 & $\begin{array}{l}0 \\
0 \\
0\end{array}$ & $\frac{\omega}{\infty}$ & v & 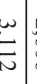 & م. & $\begin{array}{l}0 \\
0 \\
0 \\
0\end{array}$ & $\begin{array}{l}N \\
\stackrel{\infty}{\infty} \\
\stackrel{\sim}{N}\end{array}$ & $\begin{array}{l}\stackrel{N}{0} \\
\stackrel{\circ}{\sim}\end{array}$ & \begin{tabular}{|l|l|} 
\\
0 \\
0 \\
0 \\
0
\end{tabular} & $\mid \begin{array}{l}\sim \\
\underset{\mathbb{U}}{\infty} \\
\infty\end{array}$ & 岕 & 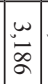 & \begin{tabular}{|c|}
\multirow{2}{*}{} \\
$\infty$ \\
$\infty$ \\
$\alpha$ \\
$\alpha$
\end{tabular} & 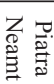 \\
\hline$\left|\begin{array}{l}\omega \\
\vdots \\
0 \\
\perp\end{array}\right|$ & $\left|\begin{array}{l}w \\
\ddot{u} \\
\sigma\end{array}\right|$ & $\begin{array}{l}\omega \\
\vec{t} \\
\vec{\sigma}\end{array}$ & $\begin{array}{l}\stackrel{N}{\sim} \\
\stackrel{0}{0} \\
0\end{array}$ & $\frac{w}{u}$ & $\left|\begin{array}{l}n \\
0 \\
0 \\
0 \\
0\end{array}\right|$ & $\begin{array}{l}\tilde{N} \\
\vec{a}\end{array}$ & $\underset{\substack{\tilde{u} \\
\sim}}{\sim}$ & : & $\mid \begin{array}{l}\sim \\
\vdots \\
\vdots \\
\omega \\
\omega\end{array}$ & $\begin{array}{l}w \\
\vdots \\
b \\
b\end{array}$ & $\overrightarrow{0}$ & & & & 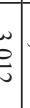 & $\begin{array}{c}w \\
w \\
0 \\
0\end{array}$ & : & $\begin{array}{l}\overrightarrow{0} \\
0 \\
0 \\
0\end{array}$ & 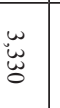 & 峁 & $\mid$ & $\left|\begin{array}{c}n \\
0 \\
0 \\
\infty \\
\infty\end{array}\right|$ & 岕 & $\left|\begin{array}{l}w \\
\ddot{\circ} \\
\ddot{\sigma}\end{array}\right|$ & $\mid$\begin{tabular}{|l}
$\omega$ \\
0 \\
0 \\
0
\end{tabular} & 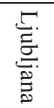 \\
\hline 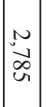 & \begin{tabular}{|c|c|}
$\omega$ \\
$\Xi$
\end{tabular} & 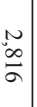 & N & 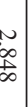 & 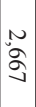 & $\stackrel{\sim}{N}$ & 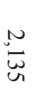 & $\mid$ & 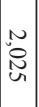 & 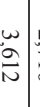 & $\stackrel{c}{c}$ & 2 & 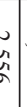 & 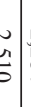 & ư & $\begin{array}{l}u^{\prime} \\
\end{array}$ & $\begin{array}{c}. \\
\\
\end{array}$ & $\vec{E}$ & 岕 & $\stackrel{N}{\stackrel{N}{ \pm}} \underset{+}{+}$ & $\begin{array}{l}N \\
\sim \\
\sim \\
O\end{array}$ & 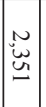 & 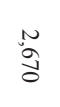 & $\begin{array}{l}\omega \\
\stackrel{\omega}{\Delta} \\
\dot{N}\end{array}$ & \begin{tabular}{|l|}
$\tilde{N}$ \\
0 \\
$\omega$ \\
$\omega$
\end{tabular} & 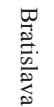 \\
\hline $\mid \begin{array}{l}N \\
\infty \\
\infty \\
+ \\
+\end{array}$ & $\stackrel{\omega}{\Xi}$ & 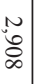 & $\begin{array}{c}\tilde{N} \\
\stackrel{\Xi}{\Xi}\end{array}$ & $\infty$ & \begin{tabular}{l}
$n$ \\
$\infty$ \\
0 \\
\hdashline \\
$ن$
\end{tabular} & 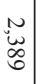 & $\stackrel{\stackrel{N}{\omega}}{\Xi}$ & $\begin{array}{l}\breve{\Delta} \\
\stackrel{\infty}{\infty}\end{array}$ & 永 & 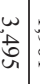 & $\vec{\bullet}$ & & & 台 & P & 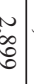 & م. & s. & $\stackrel{\omega}{\infty}$ & $\stackrel{N}{\AA}$ & \begin{tabular}{|c|}
$\omega$ \\
$\ddot{\theta}$
\end{tabular} & $\mid \begin{array}{l}N \\
\stackrel{N}{2} \\
\sigma\end{array}$ & 总 & 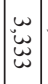 & 岕 & $\begin{array}{l}\text { त्रे } \\
\text { o. } \\
\text {. }\end{array}$ \\
\hline $\mid \begin{array}{l}n \\
0 \\
0 \\
0 \\
f\end{array}$ & $\stackrel{\omega}{\vdots}$ & $\begin{array}{l}\omega \\
0 \\
0 \\
0 \\
0\end{array}$ & 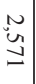 & $\tilde{N}$ & $\begin{array}{c}n \\
\tilde{u} \\
+ \\
\infty\end{array}$ & 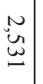 & $\begin{array}{l}\tilde{u} \\
\ddot{~}\end{array}$ & 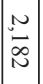 & 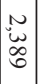 & $\begin{array}{l}n \\
\vdots \\
\vdots \\
0\end{array}$ & N & & & 0 & in & 6 & $\sigma$ & $\begin{array}{l}\vec{v} \\
\vec{b} \\
\vec{b}\end{array}$ & 䓌 & 芯 & 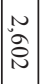 & $\mid \begin{array}{l}\tilde{N} \\
\vec{N} \\
\vec{v}\end{array}$ & $\underset{\substack{n \\
\infty}}{\stackrel{\infty}{\infty}}$ & 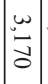 & $\begin{array}{l}\tilde{N} \\
\overrightarrow{\vec{a}} \\
\boldsymbol{f}\end{array}$ & 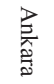 \\
\hline 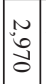 & $\mid \begin{array}{l}w \\
w \\
t \\
t\end{array}$ & 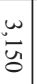 & 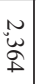 & & 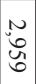 & 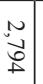 & $\stackrel{N}{\underset{D}{D}}$ & \begin{tabular}{|l|} 
\\
$\stackrel{N}{\sigma}$
\end{tabular} & 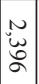 & 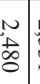 & -1 & & & & & 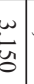 & J & 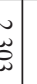 & 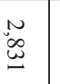 & $\begin{array}{l}N \\
\stackrel{\infty}{\infty} \\
\underset{u}{\infty}\end{array}$ & $\begin{array}{l}\mathrm{N} \\
\mathrm{N} \\
\mathrm{N}\end{array}$ & $\mid \begin{array}{l}N \\
\infty \\
\infty \\
b \\
b\end{array}$ & $\begin{array}{l}\tilde{N} \\
\stackrel{\sim}{\circ} \\
\stackrel{0}{0}\end{array}$ & \begin{tabular}{|c|} 
\\
$\ddot{\omega}$ \\
$\dot{\delta}$
\end{tabular} & \begin{tabular}{|l|} 
\\
0 \\
0 \\
0 \\
\end{tabular} & 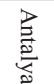 \\
\hline $\mid \begin{array}{c}N \\
\stackrel{N}{0} \\
o\end{array}$ & 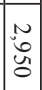 & 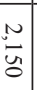 & $\begin{array}{l}\overrightarrow{8} \\
\stackrel{8}{0}\end{array}$ & & $\begin{array}{l}n \\
0 \\
0 \\
u \\
\end{array}$ & 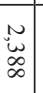 & $\begin{array}{l}\stackrel{N}{u} \\
\stackrel{\Delta}{u} \\
u\end{array}$ & 5 & $\mid \begin{array}{l}\tilde{N} \\
\tilde{u} \\
\mathrm{~d}\end{array}$ & 0 & $\vec{\omega}$ & & & & & & & S. & & $\stackrel{N}{\stackrel{N}{ \pm}}$ & $\begin{array}{l}N \\
\underset{\sim}{\sim} \\
\perp\end{array}$ & 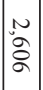 & 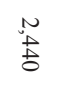 & 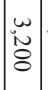 & 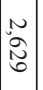 & $\begin{array}{l}\overrightarrow{\bar{n}} \\
\overrightarrow{\tilde{E}} \\
\underline{E}\end{array}$ \\
\hline
\end{tabular}

